\title{
DYNAMIC CAPABILITIES FOR DEVELOPMENT AND ENHANCEMENT OF BODY MOTRICITY AND PSICHOMOTRIC ABILITIES OF MILITAR STUDENTS BY ADAPTED MEANS FROM MARTIAL ARTS
}

\author{
Gheorghe MIHALACHE ${ }^{1}$ \\ ${ }^{1}$ University assistant, Department of Military Training, Air Force Academy “Henri Coandă”, Brasov, Romania
}

\begin{abstract}
Through this study we aimed to emphasize that the development of body motricity and psychomotric abilities by means adapted from martial arts to students from military academic world would be possible if we systematically aim at each training lesson and throughout the entire experimental cycle, fulfilment of the aims of the utmost importance (in terms of body motricity and psychomotric training), the enhancement of specialized physical exercise (specific to martial arts) with defining role in the improvement and fulfilment of personality and the preparedness of future multilateral fighters.
\end{abstract}

Key words: body motricity, psychomotric, ability.

\section{INTRODUCTION}

The popularity of martial arts, as well as their performance in terms of sports, is highlighting the astonishing excellence of human body motricity, as a synthesis of bio-psycho-motric events, with correspondence in the true sense of the word during the show created by practitioners of these forms of combat on various occasions.

Due to versatility and diversity, martial arts in general can be practiced by children, young people, older people, regardless of gender or religion, health and harmonious physical development as forms of sporting event (competition), but also as a special system of selfdefence, especially in the military academic institutions. Specialists aim to identify the most effective ways to develop and improve body motricity and psychomotric skills and to optimize the capacity the integration of innovative techniques and strategies $[4,6,7]$.

The topic discussed by us in this context, the research that we have undertaken, becomes tinged special thanks to the scientific approach, through which we deepen information about peculiarities of formation and development of body motricity and psychomotric skills to the students from military academic (Air Force Academy) in our case, not only through the means adapted martial arts in general and aikido in particular, the importance of capacity motor and psychomotor which determine directly the level of general physical training and specific and particularly technical execution of practitioners $[3$, 2].

It is essential to identify specific requests from a martial arts expressed portfolio mix driving skills, strength, speed, endurance, coordination, mobility and flexibility, focusing on body motricity and psychomotric manifestations of military students. Martial arts performance level depends on many factors like "genetic heritage" as "critical point" from which the training and education programs are oriented on cultivating habits and skills specific body motricity in an evolutionary strategy based on periodic development. Although there is no "recipe" that develops dramatically the performance capability of subjects, training programs can be design continuously correlated with the particular requirements specific to students and military. The large number of data does not necessarily ensure accuracy and correlation but rather need a methodology to capture dynamic developments. But there is also the possibility of implementing new strategies to streamline the results based on synergistic mix of dynamic capabilities and real options in a broader framework that considers and recovery elements $[6,7]$.

\section{THE GOAL AND OBJECTIVES OF THE} PROPOSED RESEARCH

The purpose of the research is in official use of martial arts means adapted for training and retraining of body motricity and psychomotric skills, physical development harmonious awareness of the possibilities of movement and body segments, separately and as a whole, the static and dynamic balance, space-time orientation, stimulating the imagination, foster creativity, speed decision-making, etc. Lack of competitiveness factors characteristics of martial sports training (physical training, technical and tactical training, psychological training, theoretical) require deepening strategies used in developing, enhancing and improving body motricity and psychomotric skills of military students.

The research emphasizes the following general objective:

- Education/ development of collaborative skills, team spirit, the overtaking, adapt quickly 
"Mircea cel Batran" Naval Academy Scientific Bulletin, Volume XIX - 2016 - Issue 2

The journal is indexed in: PROQUEST / DOAJ / Crossref / EBSCOhost / INDEX COPERNICUS / DRJI /

OAJI / JOURNAL INDEX / I2OR / SCIENCE LIBRARY INDEX / Google Scholar / Academic Keys/ ROAD Open Access / Academic Resources / Scientific Indexing Services / SCIPIO / JIFACTOR

depending on the situation, acquiring new experiences in professional perfection;

- Advice and guidance of the students in building a complex system of self-defence, resulting in the free practice of physical exercise, and particularly specialized techniques of martial arts (aikido, judo, karate, etc.).

Theoretical objectives are:

-Identifying the optimal necessary for developing, enhancing and improving body motricity and psychomotric abilities of young combatants;

-Deepen the knowledge about age peculiarities and the level of training of students;

-Establishing training programs for the next period and correlations with intermediate and macro-workout cycles;

-Establish specific correlations to allow the development of knowledge to design longterm training strategies.

Practical objectives are:

- Drafting an adapted training project in martial arts, but also compatible with "The Graduate Model" from military higher education;

- Establish a strategy for training and its effectiveness argument experimental contributions to be strengthened in specific missions that will meet future officer.

the following:

Hypothesis of the proposed research are

- Starting from educable characteristic traits of the subjects age (19-21 years), it is possible to significantly improve the efficiency of education / development of body motricity and psychomotric skills of military students;

- If education/ development of body motricity and psychomotric skills of military students by means adapted from martial arts, will have resonance on biological development, body motricity and psychomotric skills, social and perfection of their personality, then it would be possible to increase synergistic decisive physical layer, psychologically and professionally.

THE MEANS OF IMPLEMENTING SPECIFIC TESTS

We used the testing method in experimental research into three sections, namely the initial, intermediate and final to determine the level of progress psychomotric of the two groups of military students subject to research. It has considered eliminating the factors that may disturb both the reviewer and subjects, determined by:

- $\quad$ physical and mental fatigue of the subjects;

- physical and mental fatigue of the examiner;

- unprofessional management of materials necessary for testing;
- psychological climate of detente and relaxation, poor quality (weak or too strong lighting, unventilated spaces, noises).

The experiment was conducted inside of "Air Force Academy" - Henri Coanda" with students of this university, organized in two groups ( $2 \times 32)$, for a period of 2 years.

Data recording was performed on three stages (initial evaluation, early to see the overall level of preparation, the first year the interim evaluation and final evaluation at the end of the second year). The results were presented in tables and plotted, which enabled comparisons to be made interesting relief that both groups have significantly improved the level of training, but the members of the experimental group achieved better results due to the training programmes used, inspired and adapted from martial arts.

STATISTICAL ANALYSIS OF THE OBTAINED RESULTS TO THE GENERAL PSYCHOMOTRIC EVALUATION TESTS

a) Clap push-ups (simultaneous with hands and feet);

b) High jumps on judo mats $(1 \mathrm{~m})$ of squat and return to starting position to jump, squat and turn to $360^{\circ}$;

c) Standing long jumps (two jumps connected);

d) Pull-ups from a chin-up bar, with stops (isometric).

Figures 1-4 are showing the obtained results at each of 3 evaluations by the subjects of experimental group.

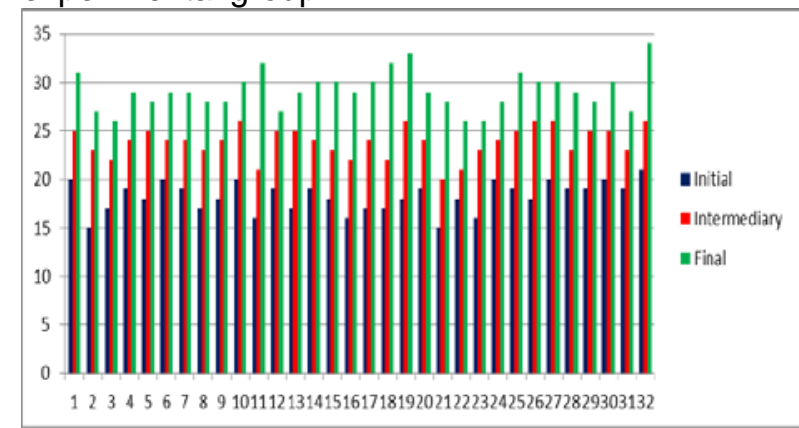

Figure 1 - Clap push-ups (simultaneous with hands and feet)

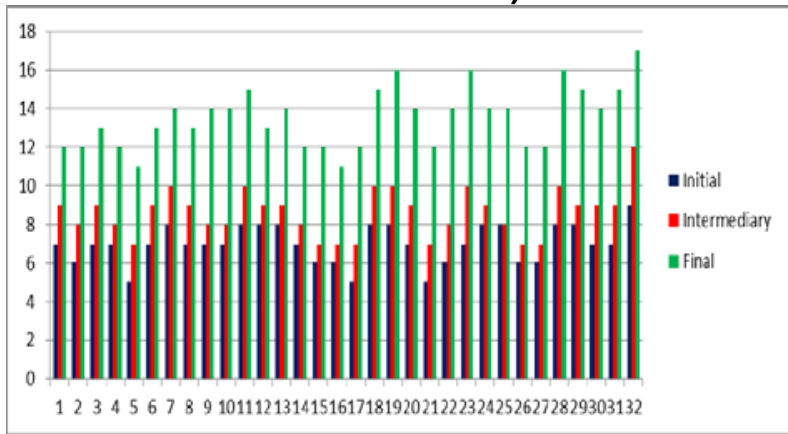

Figure 2 - High jumps on judo mats $(1 \mathrm{~m})$ of squat and return to starting position to jump, squat and turn to $360^{\circ}$ 
"Mircea cel Batran" Naval Academy Scientific Bulletin, Volume XIX - 2016 - Issue 2

The journal is indexed in: PROQUEST I DOAJ / Crossref / EBSCOhost / INDEX COPERNICUS I DRJI / OAJI / JOURNAL INDEX / I2OR / SCIENCE LIBRARY INDEX / Google Scholar / Academic Keys/ ROAD Open Access / Academic Resources / Scientific Indexing Services / SCIPIO / JIFACTOR

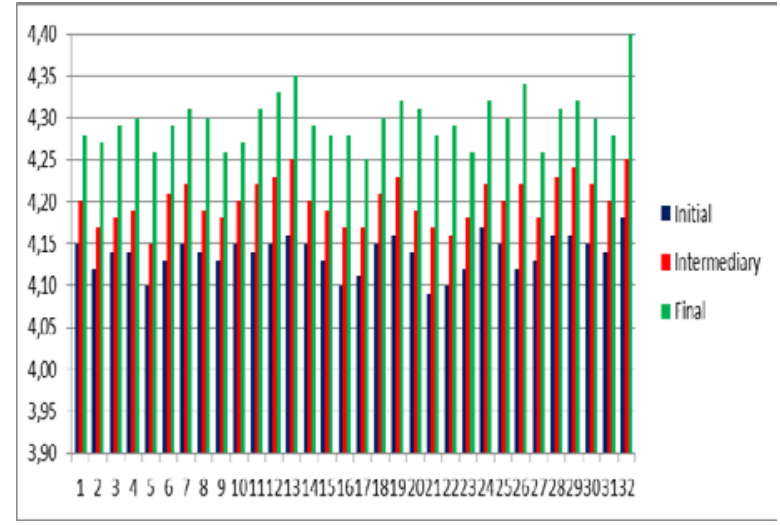

Figure 3 - Standing long jumps (two jumps connected)

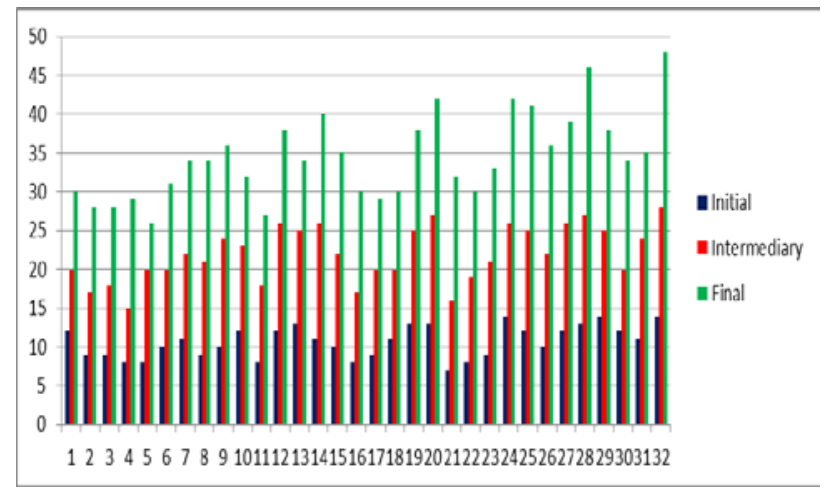

Figure 4 - Pull-ups from a chin-up bar, with stops (isometric).

Figures 5-8 emphasize the obtained results at each of 3 evaluations by the subjects of the control group.

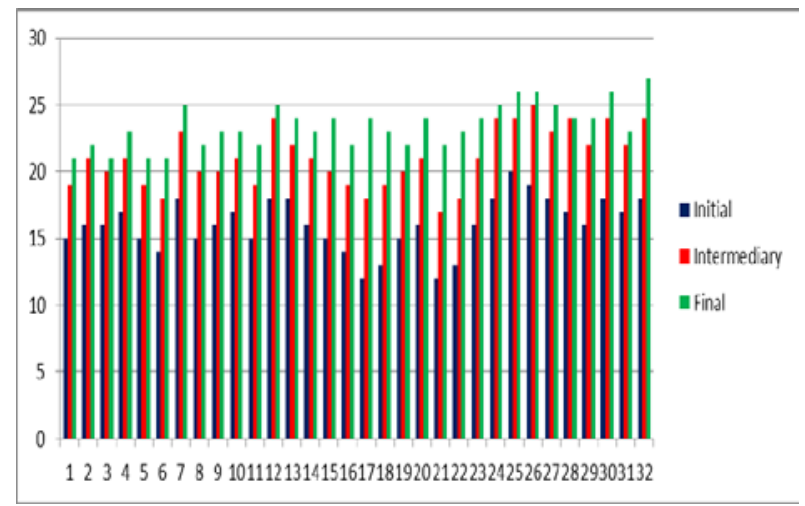

Figure 5 - Clap push-ups (simultaneous with hands and feet) - control group

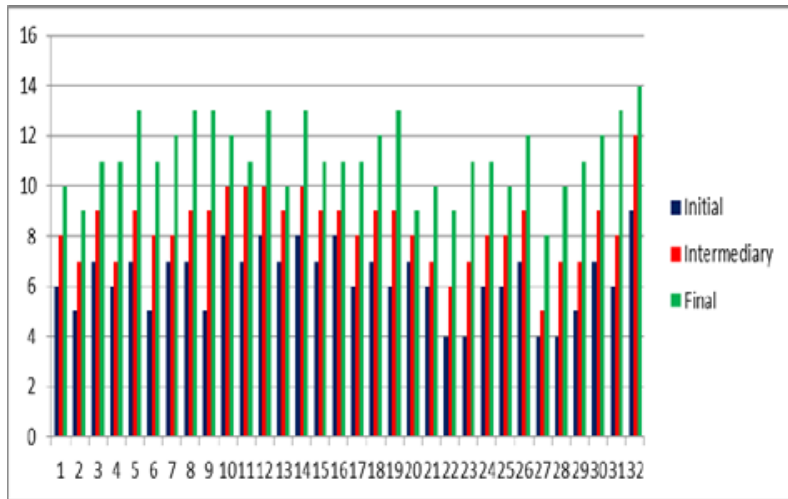

Figure 6 - High jumps on judo mats $(1 \mathrm{~m})$ of squat and return to starting position to jump, squat and turn to $360^{\circ}$ - control group

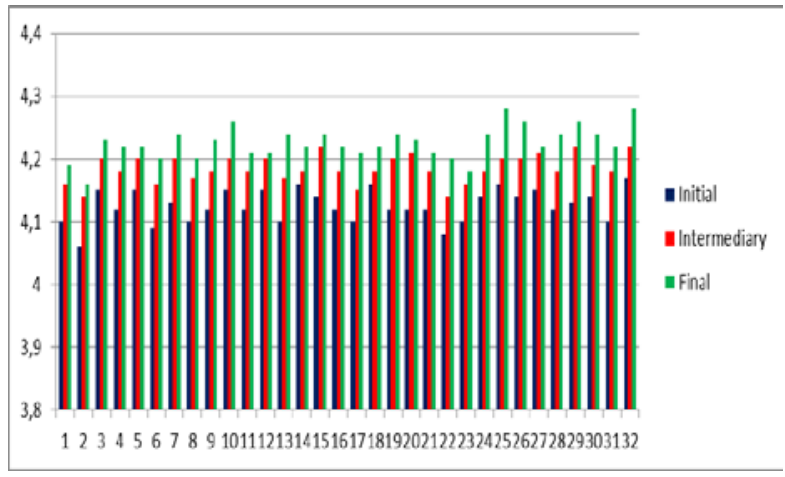

Figure 7 - Standing long jumps (two jumps connected) - control group

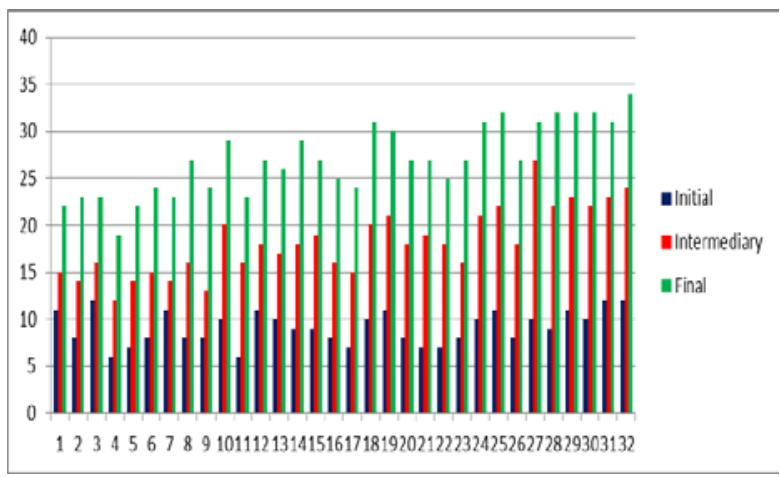

Figure 8 - Pull-ups from a chin-up bar, with stops (isometric) - control group

Analyzing the figures 1-8 we can easily observe the superiority of the performances of subjects from experimental group compared to the control group subjects.

Next we decided to do a comparative analysis of the progress made by the two groups after the workout. These advances were calculated as the difference between the initial and final performance relative to the initial performance. 
"Mircea cel Batran" Naval Academy Scientific Bulletin, Volume XIX - 2016 - Issue 2

The journal is indexed in: PROQUEST / DOAJ / Crossref / EBSCOhost / INDEX COPERNICUS / DRJI /

OAJI / JOURNAL INDEX / I2OR / SCIENCE LIBRARY INDEX / Google Scholar / Academic Keys/ ROAD Open Access / Academic Resources / Scientific Indexing Services / SCIPIO / JIFACTOR

The result was converted to percentage rates of growth/ development. Figures 9 to 12 are presented compared to the relative progress (in percentage) made by the two groups.

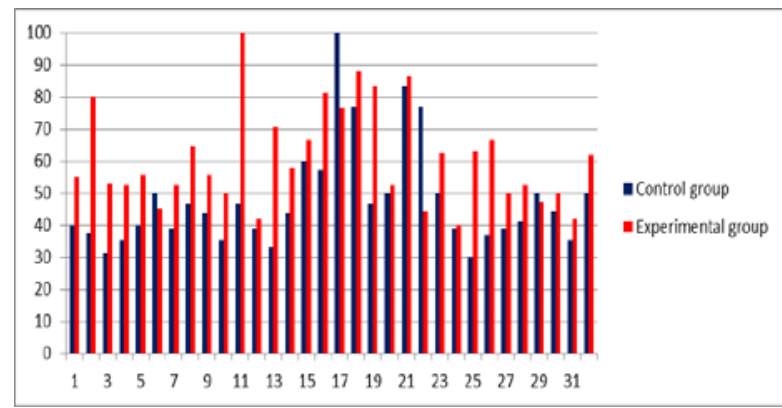

Figure 9 - Comparison for clap push-ups (simultaneous with hands and feet)

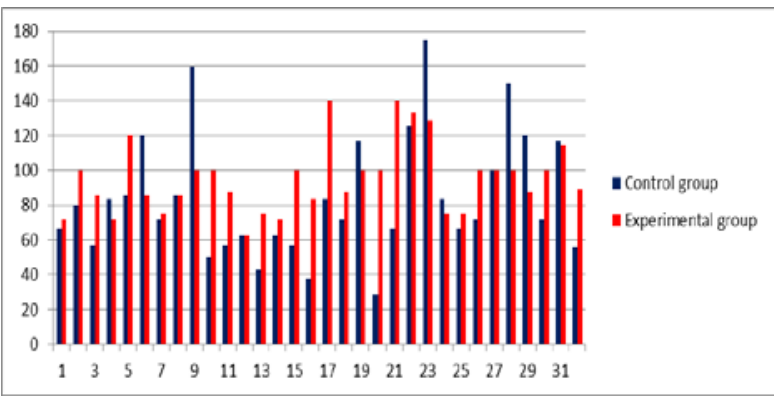

Figure 10 - Comparison for High jumps on judo mats $(1 \mathrm{~m})$ of squat and return to starting position to jump, squat and turn to $360^{\circ}$

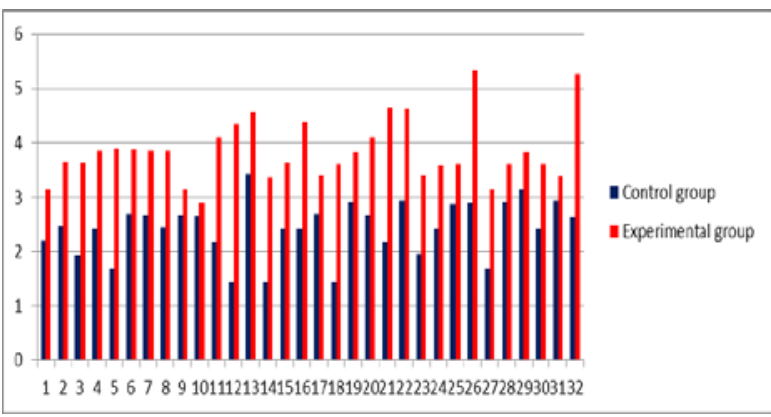

Figure 11 - Comparison for Standing long jumps (two jumps connected)

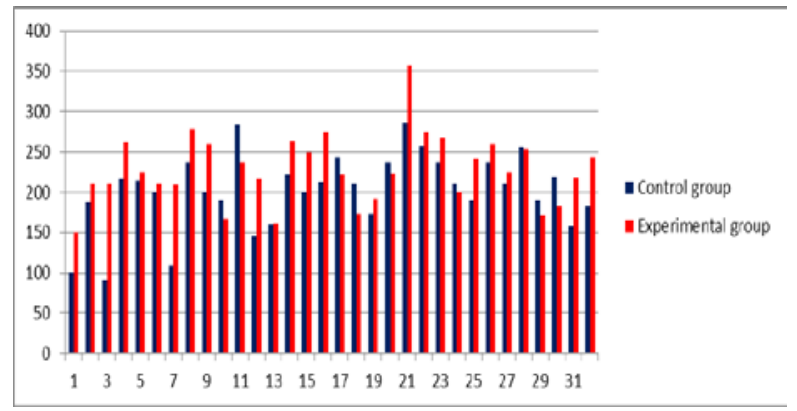

Figure 12 - Comparison for Pull-ups from a chin-up bar, with stops (isometric)
The comparisons are presented in Figures 9-12 and shortly briefed in Table 1:

Table 1 - Sinthesys of comparisons

\begin{tabular}{|c|c|c|c|c|c|}
\hline & \multicolumn{4}{|c|}{ Exercise } \\
\hline & & $\begin{array}{c}\text { Clap } \\
\text { push- } \\
\text { ups }\end{array}$ & $\begin{array}{l}\text { High } \\
\text { jumps }\end{array}$ & $\begin{array}{c}\text { Stan } \\
\text { ding } \\
\text { long } \\
\text { jumps }\end{array}$ & $\begin{array}{l}\text { Pull- } \\
\text { ups }\end{array}$ \\
\hline Experi & Mean & $60.96 \%$ & $95.15 \%$ & $3.85 \%$ & $227.9 \%$ \\
\hline $\begin{array}{c}\text { mental } \\
\text { Group }\end{array}$ & $\begin{array}{l}\text { Standard } \\
\text { deviation }\end{array}$ & $15.33 \%$ & $20.33 \%$ & $0.58 \%$ & $43 \%$ \\
\hline Control & Mean & $47.74 \%$ & $83.79 \%$ & $2.43 \%$ & $\begin{array}{c}202.19 \\
\%\end{array}$ \\
\hline Group & $\begin{array}{l}\text { Standard } \\
\text { deviation }\end{array}$ & $16.03 \%$ & $35.29 \%$ & $0.51 \%$ & $46.68 \%$ \\
\hline
\end{tabular}

Analyzing the results shown in Table 1, it is clear that if the experimental group average progress made after the workout is higher compared to that achieved by the control group. Also, the standard deviation is lower in the experimental group, an important element in military applications where the focus is team oriented.

You can observe that if the experimental group, in addition to individual performance increases, a critical effect of the workout proposed is homogenization of performance, with a degree of scattering significantly lower compared to the control group. This observation may be an argument to support the qualitative and quantitative development of the proposed training program highlighting novel vectors for efficient training methods used in working with experimental group, applicable in a broader framework.

To validate the results presented a statistical analysis should be performed. To this end using the $t$ test (Student) bilateral or deny that checks the null hypothesis, $\mathrm{H}_{0}$, which states that the two areas of varieties analyzed are equal: $m_{1}=m_{2}$. The application of the t-test is given in [8]. Tables $2 \ldots 5$ are shown the comparison of final performance with the original two groups.

Table 2 - Statistical analysis for clap push-ups, initial vs. final

\begin{tabular}{|c|c|c|c|c|c|c|}
\hline \multirow{2}{*}{$\begin{array}{l}\text { Clap } \\
\text { ups }\end{array}$} & \multirow[t]{2}{*}{ push } & \multirow{2}{*}{$\begin{array}{l}\text { No. of } \\
\text { sub } \\
\text { jects }\end{array}$} & \multirow{2}{*}{ Mean } & \multirow{2}{*}{$\begin{array}{c}\text { Stan } \\
\text { dard } \\
\text { devia } \\
\text { tion }\end{array}$} & \multicolumn{2}{|c|}{$\begin{array}{c}\text { Test } \\
\text { „Student” }\end{array}$} \\
\hline & & & & & $\mathbf{t}$ & p \\
\hline \multirow{2}{*}{$\begin{array}{l}\text { Control } \\
\text { group }\end{array}$} & Initial & 32 & 16.03 & \begin{tabular}{|l|}
1.97 \\
\end{tabular} & \multirow{2}{*}{27.545} & \multirow{2}{*}{$<0.01$} \\
\hline & \begin{tabular}{|l} 
Final \\
\end{tabular} & 32 & 26.47 & 1.70 & & \\
\hline \multirow{2}{*}{$\begin{array}{c}\text { Experi } \\
\text { mental } \\
\text { group }\end{array}$} & Initial & 32 & 18.22 & 1.56 & \multirow[b]{2}{*}{29.55} & \multirow[b]{2}{*}{$<0.01$} \\
\hline & Final & 32 & 29.16 & 1.96 & & \\
\hline
\end{tabular}


"Mircea cel Batran" Naval Academy Scientific Bulletin, Volume XIX - 2016 - Issue 2

The journal is indexed in: PROQUEST / DOAJ / Crossref / EBSCOhost / INDEX COPERNICUS / DRJI /

OAJI / JOURNAL INDEX / I2OR / SCIENCE LIBRARY INDEX / Google Scholar / Academic Keys/ ROAD Open Access / Academic Resources / Scientific Indexing Services / SCIPIO / JIFACTOR

Table 3 - Statistical analysis for high jumps, initial vs. final

\begin{tabular}{|c|c|c|c|c|c|c|}
\hline \multirow{2}{*}{\multicolumn{2}{|c|}{ High jumps }} & \multirow{2}{*}{$\begin{array}{c}\text { No. of } \\
\text { sub } \\
\text { jects }\end{array}$} & \multirow[b]{2}{*}{ Mean } & \multirow{2}{*}{$\begin{array}{l}\text { Stan } \\
\text { dard } \\
\text { devi } \\
\text { ation }\end{array}$} & \multicolumn{2}{|c|}{ Test „Student” } \\
\hline & & & & & $\mathrm{t}$ & p \\
\hline Contro & Initial & 32 & 6.31 & 1.31 & \multirow{2}{*}{21.59} & \multirow{2}{*}{$<0.01$} \\
\hline group & Final & 32 & 12.28 & 1.53 & & \\
\hline \multirow{2}{*}{$\begin{array}{l}\text { Experi } \\
\text { mental } \\
\text { group }\end{array}$} & Initial & 32 & 7 & 1.02 & \multirow[b]{2}{*}{35.3} & \multirow[b]{2}{*}{$<0.01$} \\
\hline & Final & 32 & 13.53 & 1.57 & & \\
\hline
\end{tabular}

Table 4 - Statistical analysis for standing long jumps, initial vs. final

\begin{tabular}{|c|c|c|c|c|c|c|}
\hline \multirow{2}{*}{$\begin{array}{l}\text { Standing } \\
\text { jumps }\end{array}$} & \multirow{2}{*}{ long } & \multirow{2}{*}{$\begin{array}{l}\text { No. of } \\
\text { sub } \\
\text { jects }\end{array}$} & \multirow[b]{2}{*}{ Mean } & \multirow{2}{*}{$\begin{array}{l}\text { Stan } \\
\text { dard } \\
\text { devi } \\
\text { ation } \\
\end{array}$} & \multicolumn{2}{|c|}{ Test „Student” } \\
\hline & & & & & $t$ & p \\
\hline \multirow{2}{*}{$\begin{array}{c}\text { Control } \\
\text { group }\end{array}$} & Initial & 32 & 4.13 & 0.03 & \multirow{2}{*}{27.4} & \multirow{2}{*}{$<0.01$} \\
\hline & Final & 32 & 4.27 & 0.03 & & \\
\hline \multirow{2}{*}{$\begin{array}{c}\text { Experi } \\
\text { mental } \\
\text { group }\end{array}$} & Initial & 32 & 4.14 & 0.02 & \multirow[b]{2}{*}{37.85} & \multirow[b]{2}{*}{$<0.01$} \\
\hline & Final & 32 & 4.3 & 0.03 & & \\
\hline
\end{tabular}

Table 5 - Statistical analysis for pull-ups, initial vs. final

\begin{tabular}{|c|c|c|c|c|c|c|}
\hline \multirow{2}{*}{\multicolumn{2}{|c|}{$\begin{array}{l}\text { Pull-ups from } \\
\text { chin-up bar }\end{array}$}} & \multirow{2}{*}{$\begin{array}{l}\text { No. of } \\
\text { sub } \\
\text { jects }\end{array}$} & \multirow{2}{*}{ Mean } & \multirow{2}{*}{$\begin{array}{l}\text { Stan } \\
\text { dard } \\
\text { devi } \\
\text { ation }\end{array}$} & \multicolumn{2}{|c|}{ Test „Student” } \\
\hline & & & & & $t$ & p \\
\hline Control & Initial & 32 & 9.16 & 1.78 & \multirow{2}{*}{31.89} & \multirow{2}{*}{$<0.01$} \\
\hline group & Final & 32 & 30.03 & 4.21 & & \\
\hline Experi & Initial & 32 & 10.69 & 2.06 & \multirow[b]{2}{*}{32.3} & \multirow[b]{2}{*}{$<0.01$} \\
\hline $\begin{array}{c}\text { mental } \\
\text { group }\end{array}$ & Final & 32 & 34.53 & 5.5 & & \\
\hline
\end{tabular}

Since the default materiality test "Student" implemented in MSExcel is $95 \%$, and it is used in assays presented in Tables $2 \ldots 5$, that the null hypothesis is accepted if the probability determined by applying the test check inequality

$$
\mathrm{p}>\alpha=1-95 \%=5 \%=0.05 \text { [1] }
$$

It can easily ascertain that all probabilities mentioned above do not satisfy this condition, so must accept the alternative hypothesis (contrary), that analyzed different environments. In other words, the progress made by members of both groups and outlined in Figures $1 \ldots 8$ are not random but is the result of the training performed.

To make a comparison of the training programs established for both groups, it is useful to compare their statistics in the initial and final moments. These comparisons were made with the help of test "t" and at the same null hypothesis $\left(H_{0}: m_{1}=m_{2}\right)$, and the results are shown in Tables 6 ... 9 .
The results are similar to those obtained from the analysis performed on each group that have rejected the hypothesis $\mathrm{H}_{0}$ (performance comparable).

Table 6 - Statistical analysis for clap push-ups, control group vs. experimental

\begin{tabular}{|c|c|c|c|c|c|c|}
\hline \multirow{2}{*}{\multicolumn{2}{|c|}{ Clap push-ups }} & \multirow{3}{*}{$\begin{array}{c}\begin{array}{c}\text { No. of } \\
\text { sub } \\
\text { jects }\end{array} \\
32\end{array}$} & \multirow{3}{*}{$\begin{array}{l}\text { Mean } \\
16.03\end{array}$} & \multirow{3}{*}{$\begin{array}{l}\begin{array}{c}\text { Stan } \\
\text { dard } \\
\text { devi } \\
\text { ation }\end{array} \\
1.97\end{array}$} & \multicolumn{2}{|c|}{ Test „Student” } \\
\hline & & & & & & \\
\hline \multirow[b]{2}{*}{ Initial } & $\begin{array}{l}\text { Control } \\
\text { group }\end{array}$ & & & & \multirow[b]{2}{*}{6.93} & \multirow[b]{2}{*}{$<0.01$} \\
\hline & $\begin{array}{c}\text { Experi } \\
\text { mental } \\
\text { group }\end{array}$ & 32 & 18.22 & 1.56 & & \\
\hline \multirow[b]{2}{*}{ Final } & $\begin{array}{l}\text { Control } \\
\text { group }\end{array}$ & 32 & 26.47 & 1.70 & \multirow[b]{2}{*}{14.68} & \multirow[b]{2}{*}{$<0.01$} \\
\hline & $\begin{array}{l}\text { Experi } \\
\text { mental } \\
\text { group }\end{array}$ & 32 & 29.16 & 1.96 & & \\
\hline
\end{tabular}

Table 7 - Statistical analysis for high jumps, control group vs. experimental

\begin{tabular}{|c|c|c|c|c|c|c|}
\hline \multirow{2}{*}{\multicolumn{2}{|c|}{ High jumps }} & \multirow{3}{*}{\begin{tabular}{|c|}
$\begin{array}{c}\text { No. of } \\
\text { sub } \\
\text { jects }\end{array}$ \\
32
\end{tabular}} & \multirow{3}{*}{$\begin{array}{l}\text { Mean } \\
6.31\end{array}$} & \multirow{3}{*}{$\begin{array}{l}\begin{array}{l}\text { Stan } \\
\text { dard } \\
\text { devi } \\
\text { ation }\end{array} \\
1.31\end{array}$} & \multicolumn{2}{|c|}{ Test „Student” } \\
\hline & & & & & $t$ & p \\
\hline \multirow[b]{2}{*}{ Initial } & \begin{tabular}{|c|} 
Control \\
group
\end{tabular} & & & & \multirow[b]{2}{*}{2.61} & \multirow[b]{2}{*}{0.014} \\
\hline & \begin{tabular}{|c} 
Experi \\
mental \\
group
\end{tabular} & 32 & 7 & 1.02 & & \\
\hline \multirow[b]{2}{*}{ Final } & $\begin{array}{l}\text { Control } \\
\text { group }\end{array}$ & 32 & 12.28 & 1.53 & \multirow[b]{2}{*}{6.84} & \multirow[b]{2}{*}{$<0.01$} \\
\hline & $\begin{array}{c}\text { Experi } \\
\text { mental } \\
\text { group }\end{array}$ & 32 & 13.53 & 1.57 & & \\
\hline
\end{tabular}

Table 8 - Statistical analysis for standing long jumps, control group vs. experimental

\begin{tabular}{|c|c|c|c|c|c|c|}
\hline \multirow{2}{*}{\multicolumn{2}{|c|}{$\begin{array}{l}\text { Standing } \\
\text { jumps }\end{array}$}} & \multirow{2}{*}{$\begin{array}{l}\text { No. of } \\
\text { sub } \\
\text { jects }\end{array}$} & \multirow[b]{2}{*}{ Mean } & \multirow{2}{*}{$\begin{array}{l}\text { Stan } \\
\text { dard } \\
\text { devi } \\
\text { ation }\end{array}$} & \multicolumn{2}{|c|}{ Test „Student” } \\
\hline & & & & & $\mathbf{t}$ & p \\
\hline \multirow[b]{2}{*}{ Initial } & $\begin{array}{c}\text { Control } \\
\text { group }\end{array}$ & 32 & 4.13 & 0.03 & \multirow[b]{2}{*}{2.63} & \multirow[b]{2}{*}{0.013} \\
\hline & $\begin{array}{c}\text { Experi } \\
\text { mental } \\
\text { group }\end{array}$ & 32 & 4.14 & 0.02 & & \\
\hline \multirow[b]{2}{*}{ Final } & $\begin{array}{c}\text { Control } \\
\text { group }\end{array}$ & 32 & 4.27 & 0.03 & \multirow[b]{2}{*}{14.67} & \multirow[b]{2}{*}{$<0.01$} \\
\hline & $\begin{array}{c}\text { Experi } \\
\text { mental } \\
\text { group }\end{array}$ & 32 & 4.3 & 0.03 & & \\
\hline
\end{tabular}




\section{"Mircea cel Batran" Naval Academy Scientific Bulletin, Volume XIX - 2016 - Issue 2 The journal is indexed in: PROQUEST I DOAJ / Crossref / EBSCOhost / INDEX COPERNICUS / DRJI I OAJI / JOURNAL INDEX I I2OR / SCIENCE LIBRARY INDEX / Google Scholar / Academic Keys/ ROAD Open Access / Academic Resources / Scientific Indexing Services / SCIPIO I JIFACTOR}

Table 9 - Statistical analysis for pull-ups control group vs. experimental

\begin{tabular}{|c|c|c|c|c|c|c|}
\hline \multirow{2}{*}{\multicolumn{2}{|c|}{$\begin{array}{l}\text { Pull-ups from a } \\
\text { chin-up bar }\end{array}$}} & \multirow{3}{*}{$\begin{array}{c}\begin{array}{c}\text { No. of } \\
\text { sub } \\
\text { jects }\end{array} \\
32\end{array}$} & \multirow{3}{*}{$\begin{array}{l}\text { Mean } \\
9.16\end{array}$} & \multirow{3}{*}{$\begin{array}{l}\begin{array}{c}\text { Stan } \\
\text { dard } \\
\text { devi } \\
\text { ation }\end{array} \\
1.78\end{array}$} & \multicolumn{2}{|c|}{ Test „Student” } \\
\hline & & & & & $\mathbf{t}$ & $\mathbf{p}$ \\
\hline \multirow[b]{2}{*}{ Initial } & $\begin{array}{l}\text { Control } \\
\text { group }\end{array}$ & & & & \multirow[b]{2}{*}{5.85} & \multirow[b]{2}{*}{$<0.01$} \\
\hline & $\begin{array}{c}\text { Experi } \\
\text { mental } \\
\text { group }\end{array}$ & 32 & 10.69 & 2.06 & & \\
\hline \multirow[b]{2}{*}{ Final } & $\begin{array}{l}\text { Control } \\
\text { group }\end{array}$ & 32 & 30.03 & 4.21 & \multirow[b]{2}{*}{20.79} & \multirow[b]{2}{*}{$<0.01$} \\
\hline & $\begin{array}{c}\text { Experi } \\
\text { mental } \\
\text { group }\end{array}$ & 32 & 34.53 & 5.5 & & \\
\hline
\end{tabular}

It follows that there is a difference in baseline training for the experimental group members. However, analyzing the levels of probability calculated by the "t" test, one can say that at the end of the experiment progress of the experimental group are significantly superior to the control group (probability equal performance is quasi-null) and initial testing are two samples (the jumping - tables 7 and 8) the refutation of null hypothesis is the limit, i.e. the difference in preparation between the two groups exist, but it is not as obvious as the other two.

These comments are but two pleas in favour of training methods borrowed from martial arts.

A short description of these training methods is presented bellow.

Clap push-ups (simultaneous with hands and feet) combines three body motric qualities, respectively force (F), speed (S) and Coordination (C). Pushups are performed using hands support directly on the ground (gym hall surface) with straight arms and forearms segments, perpendicular to the ground, straight distance between them at shoulder width segments legs, shoulder-width apart, support spikes, spine extended (plain), the body generally inclined.

Repetitions are performed with simultaneous detachment from the ground of hands and legs for a split second while in which the clap in front of your chest and inside the feet. The development of this combined strength, speed, coordination using plyometric system results dominant, education/ development, explosion at arms lower and upper levels which will find applicability in simple and combined blows specific to martial arts.

High jumps on judo mats $(1 \mathrm{~m})$ of squat and return to starting position to jump squat and turn again to $360^{\circ}$ performed into a plyometric approach enables physical attributes as follows: force (F) under the speed (S) and coordination (C), and space - time orientation.
The subject will make the jump from squatting, with full support on the soles of the feet, the distance between them to the width of his/ her hips, posture torso leaning slightly forward, arms hang naturally at his sides, completely relaxed, oriented to face the mattress (by the gym hall walls) where it will fall to the ground by performing jumping and squatting will get everything in the package judo mats. From this position will jump on mattresses, rising, place of departure and swirling in $360^{\circ}$. The rotation will be performed once to the left and once to the right.

By this plyometric method, we develop force (F), under speed (S) and coordination (C), and temporal and spatial orientation with resultant explosion dominant in educating the lower limbs. Education/ development of these combined qualities are necessary in the performing of feet techniques. Legs of martial arts practitioner must be strong, ensure stability, to execute the technical structures quickly (striking techniques simple rotary $90^{\circ}, 180^{\circ}, 270^{\circ}, 360^{\circ}$ and jump, and taisabaki - return swivel).

Military fighter as martial arts practitioner will use all of these elements adapting them to the situations that will face.

Standing long jumps (two jumps connected) variant develop force (F) at the legs level. Subjects will perform this exercise of jumping from squatting, the end of first jump being the beginning of the second jump.

The connected jumps are related to the technical executions of martial arts (the end of a process is the beginning of the next) according to everchanging situations of a fight.

Military fighter in varied terrain will be forced to use two but no more connected jumps.

Pull-ups from a chin-up bar, with stops (isometric) involve force $(F)$ on resistance mode (R) isometric. Number of repeat actions is imposed as follows: 8 in the initial stage, 10 for intermediate stage and 14 in the final stage. In terms of making the repetition condition is that the lower and upper arms segments are outstretched, and at the numbers $8,10,14$ the subject stops his chin above the bar, the angle between the arms and forearms to be $90^{\circ}$, remaining in this position up to maximum effort.

We consider that this variant of pull-ups, we develop force $(F)$ in combination with resistance $(R)$ in the upper limbs, with a strong grip on the hands, and scapular-humeral joints with associated muscle groups, latissimus dorsi, etc. The combined force at this level is a need for every martial art fighter and not only.

Applicability of these two qualities in the regime described above, it is find in various combat situations (joint locking techniques, strangle techniques, pin etc.) but also when military 


\section{"Mircea cel Batran" Naval Academy Scientific Bulletin, Volume XIX - 2016 - Issue 2 \\ The journal is indexed in: PROQUEST I DOAJ / Crossref / EBSCOhost / INDEX COPERNICUS / DRJI I \\ OAJI / JOURNAL INDEX / I2OR / SCIENCE LIBRARY INDEX / Google Scholar / Academic Keys/ ROAD Open Access / Academic Resources / Scientific Indexing Services / SCIPIO I JIFACTOR}

fighters, as martial arts practitioners are forced into extreme circumstances remain suspended grabbing something (a rock, a tree branch, a liana etc.) for awhile.

\section{CONCLUSIONS}

Martial arts were and remain, due to the complexity and adaptability of their capabilities, rich sources of information and inspiration for the best performing of stun defence systems, with or without weapons or combined, necessary both to the military system and other structures (militarized) whose final objective is the preparedness of modern fighters with strong characters, easily adaptable to unforeseen circumstances. It was presented the importance of a thorough understanding of the role and the place it has the development body motricity and psychomotric system in the multilateral training of future military combat, in an approach that streamlines the process of specific training martial arts and contribute to ensuring the prerequisites for a thorough preparation on throughout their careers.

Due to research and data processing, we present the following conclusions:

- Means adapted from martial arts have been shown to be compatible with the age and the level of the subject;

- The means used in this context focused on the following components of sports training: physical training, psychological training, and theoretical training;

- Based on the results presented, there is the possibility to extent the proposed research with innovative strategies to improve the performance starting from the incorporation of new methodologies in the decision-making processes.

It should be pointed out that the spectacular results appear in the conditions in which the feed-back between teacher and those to whom it is addressed, when the drive systems are compatible with qualification, peculiarities of age and not least with professional requirements. Decision making and designing mediumand long-term strategies are essential in this endeavour.

The proposed analysis is particularly useful for analyzed subjects segment and allows highlighting some new possibilities for training and performance testing. Analysis of results in the growth performance is an important contribution to the literature, data filtering and organizing stages of tests adequately representing the organization of the proposed research. These results can be applied to design methods and innovative strategies to increase athletic performance in a faster clip. Future research could also use innovative tools and adapted decision-inspired theory of real options or dynamic capabilities.

\section{BIBLIOGRAPHY}

[1] Ionescu, D. C., Encyclopaedia of Aikido - The Art, vol. 1, MIX Publishing House, Braşov, 2005;

[2] Deliu, D., Methodology of combat sports disciplines, Bren Publishing House, Bucureşti, 2008;

[3] Ene, M. I., Judo - Multidisciplinary terminology guide, Publishing House of University Trust „Dunărea de jos" Galaţi, 2012;

[4] Mateev, L.P., Theory and methods of physical education, Sport-Tourism Publishing House, Bucureşti 1980

[5] Deliu, D., Sport training in combat in disciplines, Bren Publishing House, București, 2008;

[6] Boşcoianu, M, Bacali, L, Boăcoianu, E.C., Codreanu, A., A Real Options - based Framework for Strategic Decision - making in Hostile, Turbulent and Ultra - Volatile Environments, Applied Mechanics and Materials ISSN: 1662-7482, Vol. 841, pp 323-329, Trans Tech Publications, Switzerland, 2016;

[7] Boşcoianu, M., Cioaca, C., Vlădăreanu, V., Boşcoianu, E.C., An active support instrument for innovation in deep uncertainty - the strategic management ingredients in robotics and mechatronics, Elsevier, Procedia Computer Science 65, 2015;

[8] Mihalache, Gh., Jurat, V., Experiment on education/ development of psychomotric skills of military students. 